\title{
Evidence of HIV exposure and transient seroreactivity in archived HIV-negative severe hemophiliac sera
}

\author{
Scott A Tenenbaum*1, Cindy A Morris ${ }^{2}$, Steve S Alexander ${ }^{3}$, \\ Harris E McFerrin ${ }^{2}$, Robert F Garry ${ }^{2}$ and Cindy A Leissinger ${ }^{4}$
}

\begin{abstract}
Address: ${ }^{1}$ Department of Biomedical Sciences, Ge*NY*Sis Center for Excellence in Cancer Genomics, University at Albany-SUNY, Albany, NY, USA, ${ }^{2}$ Microbiology and Immunology, Tulane University School of Medicine, Tulane University School of Medicine, New Orleans, LA, USA, ${ }^{3}$ Ortho Diagnostic Systems, HIV and Hepatitis Research and Development, Raritan, NJ, USA and ${ }^{4}$ Department of Medicine, Section of Hematology and Medical Oncology, Tulane University School of Medicine, New Orleans, LA, USA
\end{abstract}

Email: Scott A Tenenbaum* - stenenbaum@albany.edu; Cindy A Morris - cmorris2@tulane.edu; Steve S Alexander - SAlexand@OCDUS.JNJ.COM; Harris E McFerrin - mharris1@tulane.edu; Robert F Garry - rfgarry@tulane.edu; Cindy A Leissinger - cleissi@tulane.edu

* Corresponding author

Published: 17 August 2005

Virology Journal 2005, 2:65 doi:10.1 186/1743-422X-2-65
Received: 08 August 2005

Accepted: 17 August 2005

This article is available from: http://www.virologyj.com/content/2/I/65

(c) 2005 Tenenbaum et al; licensee BioMed Central Ltd.

This is an Open Access article distributed under the terms of the Creative Commons Attribution License (http://creativecommons.org/licenses/by/2.0), which permits unrestricted use, distribution, and reproduction in any medium, provided the original work is properly cited.

\begin{abstract}
Background: Approximately $25 \%$ of hemophiliacs that were frequently exposed to blood clotting factor concentrates (CFCs) contaminated with human immunodeficiency virus (HIV) are presently HIV seronegative. In this study, we sought to determine if some of these individuals were at any time transiently HIV seropositive. In the early to mid-1980s the majority of severe hemophilia patients were exposed to CFCs contaminated with HIV. Although many of these hemophiliacs became HIV-positive, a small percentage did not become infected. To determine if some of these individuals successfully resisted viral infection, we attempted to document the presence of transient HIV reactive antibodies in archived plasma samples (1980-1992) from currently HIV-negative severe hemophiliacs who had a high probability of repeated exposure to HIV contaminated CFC. Archived plasma samples were retrospectively tested using an FDA approved HIV-IAb HIV-I/HIV2 ( $r D N A)$ enzyme immunoassay (EIA) and a HIV-I Western blot assay $(\mathrm{Wb})$, neither of which were commercially available until the late 1980s, which was after many of these samples had been drawn.

Results: We found that during the high risk years of exposure to HIV contaminated CFC (19801987), low levels of plasma antibodies reactive with HIV proteins were detectable in $87 \%$ (13/15) of the haemophiliacs tested. None of these individuals are presently positive for HIV proviral DNA as assessed by polymerase chain reaction (PCR).

Conclusion: Our data suggest that some severe hemophiliacs with heavy exposure to infectious HIV contaminated CFC had only transient low-level humoral immune responses reactive with HIV antigens yet remained HIV-negative and apparently uninfected. Our data supports the possibility of HIV exposure without sustained infection and the existence of HIV-natural resistance in some individuals.
\end{abstract}




\section{Background}

In the 1980's an estimated 17,000 people in the United States were affected the congenital blood clotting factor deficiencies, Hemophilia A and B (Factor VIII and Factor IX deficiency, respectively). Since the early 1970's, the mainstay of treatment for bleeding in hemophilia patients has been the use of clotting factor concentrates (CFCs) commercially prepared from large plasma pools comprised of thousands of individual donors. Prior to 1985 CFCs were prepared from donors with unknown HIV infection status and were not routinely subjected to viral inactivation procedures. With each infusion from a new lot of clotting factor concentrate, hemophilia patients were exposed to plasma from approximately 2,000 to 25,000 donors [1]. As a result, roughly $50 \%$ of the total hemophilia population in the United States became infected with HIV prior to the institution of donor screening and the use of viral inactivation procedures of factor concentrates in 1985 [2-4]. Since 1987 there has been a virtual elimination of HIV-1 infection in the hemophilia population [3-6].

Largely due to the extensive network of comprehensive hemophilia treatment centers, the hemophilia population has been actively studied for possible variables that may influence HIV infection and progression. Retrospective analysis of hemophiliac plasma samples stored as part of routine clinical visits has shown that HIV infection, as documented by permanent HIV-seroconversions began in 1978 , peaked in 1982, and ended by 1987 . In general, those patients who received the greatest exposure to CFCs were at the highest risk for HIV infection [7]. Hemophiliacs exposed to factor-VIII concentrates, in general, were more likely to become infected than those exposed to factor-IX concentrates (prothrombin complex concentrates or PCCs). Patients who received an average of over 20,000 units of factor-VIII concentrate annually during the early 1980's had a cumulative incidence of HIV-infection exceeding $90 \%$ and those receiving comparable doses of PCCs had a cumulative incidence exceeding 50\% [3,4]. This clearly demonstrates the prevalence of infectious HIV in the United States CFC supply.

Not all hemophiliacs exposed to CFCs contaminated with infectious HIV were ultimately infected with the HIV virus. Although inoculum size may account for the lack of infection in some hemophiliacs, factors such as age, race, sex or pre-existing medical condition has not been found to be related to risk of HIV infection. However, several studies have shown that certain HLA types were associated with either an increased or decreased risk of HIV infection in hemophilia patients [3,8-10].

In 1996, three independent groups identified the chemokine co-receptor 5 (CCR-5) as a secondary receptor for the
HIV virus. The presence of two copies of a naturally occurring deletion mutation of the CCR-5 receptor (CCR-5 $\Delta 32$ ) apparently conferred resistance to infection by the virus [11-14]. Heterozygous expression of CCR-5 $\Delta 32$ did not appear to prevent HIV-1 infection but may have resulted in slower decline in CD4+ cells, lower levels of plasma viremia and in slower progression to AIDS [15-18]. From 1979-1985 severe hemophiliacs, as defined as individuals producing less than $1 \%$ of the normal value of a clotting factor, were exposed to the largest volume of clotting factor concentrates. Accordingly, 90\% of these individuals became infected with HIV [4]. However, some severe hemophiliacs have remained $\mathrm{H}$ [V-negative despite repeated exposure to CFCs. We hypothesized that information concerning natural HIV resistance might be obtained by the investigation of such high-risk individuals. Although HIV enzyme linked immunoassays (EIA) and Western blot assays ( $\mathrm{Wb}$ ) were available for detecting antibodies reactive with HIV antigens as early as 1984, the specificities and sensitivities of these immunoassays have increased dramatically in more contemporary versions of these diagnostic tests [19-23]. We speculated that some High-risk hemophiliacs exposed to contaminated CFCs, although not permanently infected, may have mounted transient humoral and/or cellular immune responses reactive with HIV proteins but were below the threshold of delectability of the earlier first generation HIV diagnostic tests. Using more sensitive HIV immunologic diagnostic tests, we reassessed anti-HIV reactivity in archived plasma samples (1980-1992) from presently HIV-seronegative severe hemophiliacs that had exposure to large quantities of contaminated CFCs (HIV exposed/-HIV negative hemophiliacs).

\section{Results \\ Detection of transient HIV reactive plasma antibodies}

We had adequate yearly representation and sample quantity in our archived collection to assemble plasma sets from 15 severe hemophiliacs with extremely likely exposure to HIV contaminated clotting concentrates (Table 1). All of the archived plasma sets tested contained samples that were collected prior to 1986. Using improved HIVEIA or HIV-Wb immunoassay analysis we detected antibodies reactive with HIV antigens in one or more samples from 13/15 (87\%) of the archived plasma sets tested (Figure 1, panels 2-4 and Table 2, patients 1-13). Of these, two plasma sets had samples reactive to both the HIV-EIA and the HIV-WB (Figure 1, panel 2 and Table 2, patient 2 and 5). An additional three plasma sets contained samples displaying reactivity only on the HIV-EIA (Table 2, patients 1, 6 and 7) which occurred in samples collected in 1987 or earlier. Eight of the hemophilia patient archived plasma sets contained samples with antibodies (IgG and/or IgM) only reactive with one or more HIV antigen as determined by HIV-1 Wb analysis (representative 

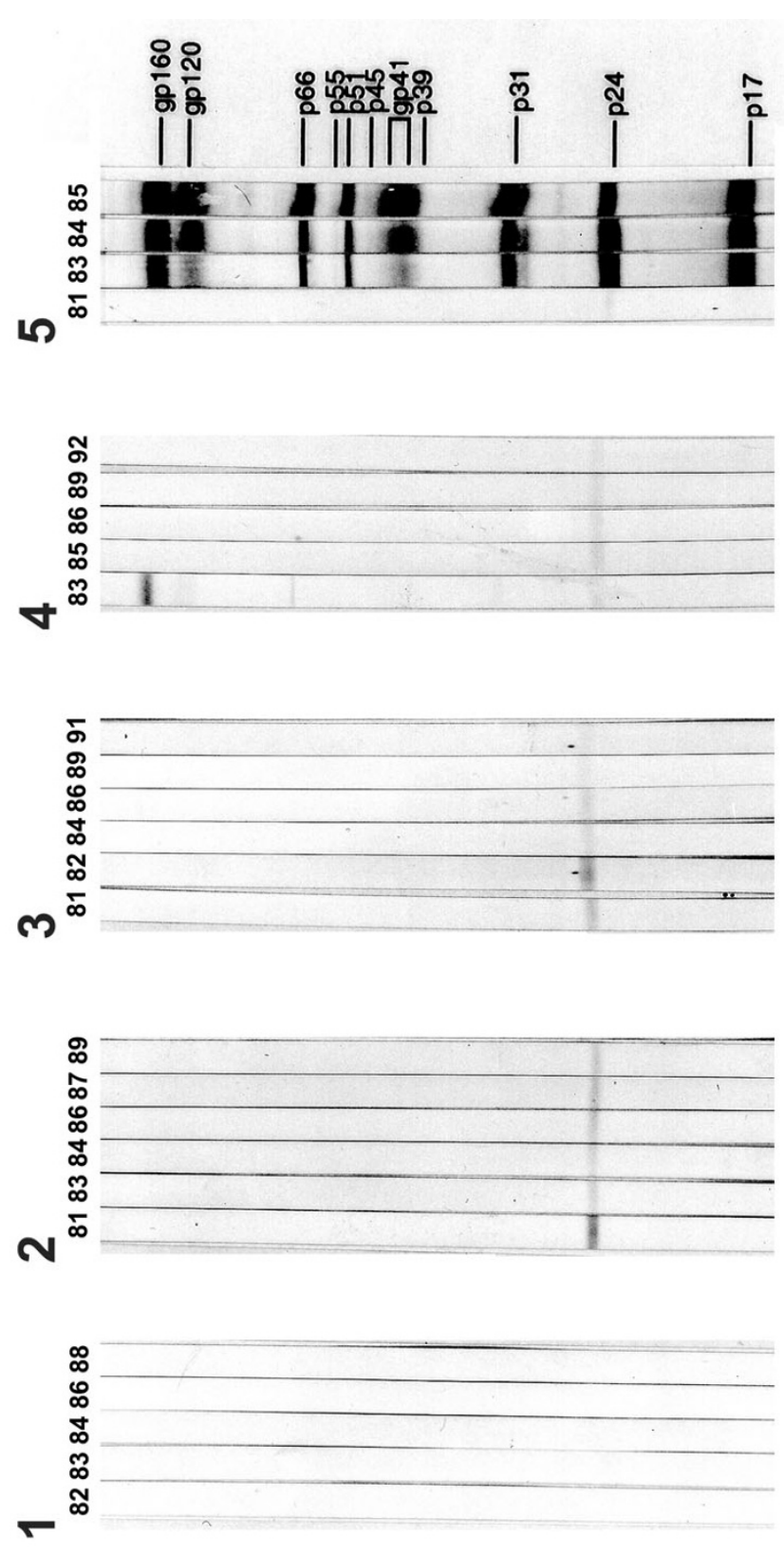

\section{Figure I}

HIV-I Western blot reactivity of HIV-exposed/HIV seronegative hemophiliacs. Panels I-4: HIV-I western blot analysis of chronologically archived plasma samples from HIV-exposed/HIV-seronegative hemophiliacs displaying transient partial reactivity against HIV-I proteins. Panel 5: Chronological serum samples from an HIV-I seropositive hemophiliac. Panel numbers $(\mathrm{I}-4)$ correspond to $I-4$ respectively in tables I and 2. examples panels 2-4, Figure 1 and Table 2, patients 3, 4, $8-13$ ). HIV proteins were recognized by antibodies in HIV-1 Wb reactive plasma samples in the following frequencies; group antigen (Gag) p17 (3/10, 30\%), group antigen (Gag) p24 (8/10, 80\%), reverse transcriptase (RT) p66 (3/10, 30\%), envelope glycoproteins (Env) gp120 and $160(2 / 10,20 \%)$, One archived plasma set contained a sample that displayed reactivity to multiple HIV antigens on HIV-1 Wb analysis that approached meeting the criteria for "HIV-positive" reactivity (Figure 1, panel 4 and table 2, patient 4). The observed multiple HIV protein reactivity was only present in the 1983 sample from this archived plasma set. As a whole, indeterminate banding activity on the HIV-1 Wb appeared to fluctuate in intensity within many of the archived plasma sets that displayed reactivity (Figure 1 panels $1-3$ and Table 2 asterisks). The greatest intensity of banding activity in these archived plasma sets coincided with years of highest-risk of exposure to HIV contaminated clotting factor concentrate (1980-1985). None of the HIV-1 Wb indeterminate hemophiliacs showed reactivity to HIV-2 proteins when analyzed by HIV-2 Wb analysis (data not shown).

\section{Assessment of current HIV-I-proviral DNA status}

Post-1990 peripheral blood mononuclear cells were assessed for the presence of HIV-1 proviral DNA in all patients whose samples showed anti-HIV-1 reactivity using HIV-1-PCR analysis (kindly performed in a blinded manner using appropriate positive and negative controls by Charles Schable at the Centers for Disease Control and Prevention, Atlanta, GA.) All currently seronegative patients were found to be negative for HIV-1 proviral DNA by PCR analysis (data not shown).

\section{Passive HIV-I reactive antibodies in clotting Factor concentrates}

It was possible that the HIV-1 activity that we detected results from the presence of passive anti-HIV antibodies that were present in a recently transfused CFC just prior to the drawing of the plasma sample we tested and therefore could be detectable in the plasma sample we tested. To assess the feasibility that the HIV-1 reactive antibodies present in contaminated CFCs could passively give rise to false-positive results in our testing, we reconstituted four factor-VIII concentrates and one PCC that were manufactured between 1981 and 1984 and tested them for the presence of anti-HIV-1 reactive antibodies. None of the reconstituted concentrates displayed reactivity on HIVEIA, although a control aliquot of reconstituted factor spiked with HIV positive serum was reactive (data not shown) suggesting that the observed HIV-1 reactivity on our assays was not the result of the passive presence of HIV-1 reactive antibodies in CFCs. The reconstituted PCC was negative by HIV-1 WB analysis, however, the reconstituted factor VIII lots were found to have HIV-1 Wb 
Table I: Clinical profile and clotting factor concentrate exposure of HIV-Exposed/HIVseronegative hemophiliacs.

\begin{tabular}{|c|c|c|c|c|c|c|}
\hline \multicolumn{5}{|c|}{ Hemophilia } & \multicolumn{2}{|c|}{ Factor concentrate exposure (1980-1985) } \\
\hline Patient \# & Year of birth & Type & Severity* & Presence of inhibitor** & Type & Average Units/year \\
\hline I & 1972 & B & $<1 \%$ & No & PCC & 55,000 \\
\hline 2 & 1956 & B & $4 \%$ & No & PCC & $<10,000$ \\
\hline 3 & 1966 & A & $<1 \%$ & Yes & PCC & 27,000 \\
\hline 4 & 1953 & $A$ & $<1 \%$ & No & VIII & 15,000 \\
\hline 5 & 1977 & B & $<1 \%$ & No & PCC & 29,000 \\
\hline 6 & 1971 & A & $<1 \%$ & Yes & PCC & 30,000 \\
\hline 7 & 1931 & A & $<1 \%$ & No & VIII & 11,000 \\
\hline 8 & 1976 & B & $<1 \%$ & No & PCC & 18,000 \\
\hline 9 & 1964 & B & $<1 \%$ & No & PCC & 24,000 \\
\hline 10 & 1976 & A & $<1 \%$ & Yes & PCC & 12,000 \\
\hline II & 1957 & A & $<1 \%$ & No & VIII & 29,000 \\
\hline 12 & 1950 & A & $<1 \%$ & Yes & PCC & 80,000 \\
\hline 13 & 1969 & B & $2 \%$ & No & PCC & 22,000 \\
\hline 14 & 1959 & A & $<1 \%$ & No & VIII & 10,000 \\
\hline 15 & 1946 & B & $<1 \%$ & No & PCC & 19,000 \\
\hline
\end{tabular}

* Normal factor VIII and Ix levels are 50-150\%

** Inhibitor indicates the presence of a circulating antibody against the deficient factor; for patients with hemophilia $A$, an inhibitor often necessitates the use of PCC instead of factor VIII concentrates to control bleeding.

reactivity at a dilution of $1: 50$ for the viral antigens p17, p24 and gpl60. One reconstituted factor HIV-1 sample had detectable anti-HIV-1 reactivity at a dilution of 1:100 (which was the dilution used for the hemophiliac plasma samples) but not beyond. No HIV-1 EIA or Wb reactivity was detected in clotting factor concentrates manufactured after 1985 (data not shown).

\section{Presence of CCR-5 deletion mutations}

To determine whether hetero- or homozygous CCR-5 deletion mutations were present in these patients, polymerase chain reaction-restriction fragment length polymorphism (PCR-RFLP) analyses were performed on samples obtained from all patients except patient 2 (Table $2)$. As expected most patients $(11 / 14)$ were homozygous for wild type CCR -5. 2 of 14 patients were heterozygous for CCR-5 $\Delta 32$. Interestingly, patient 11, who was homozygous positive for the mutation, was never infected; however, he was the most heavily exposed to the most infectious concentrate (factor VIII) and was an IV drug user. Because our laboratory has been following longitudinally a number of hemophiliacs (113) who have been exposed to CFCs, including the 15 patients followed throughout this study, we determined the CCR5 genotypes of these individuals to establish the frequency of CCR5 mutations. Expectedly, the vast majority of the hemophiliacs tested (113) were wild-type for CCR5; however, $14 / 131(10.7 \%)$ and 2/131 (1.5\%) were heterozygous and homozygous mutants of CCR5, respectively. Of these patients, 47 were HIV-1-positive, where $41 / 47$ $(87.2 \%), 6 / 47(12.8 \%)$ and $0 / 47(0 \%)$ were homozygous wild-type, heterozygous and homozygous mutant for
CCR5, in that order. Of the remaining patients that were HIV-1-negative genotyped (a total of 84 ), 74/84 (88.1\%), $8 / 84(9.5 \%)$ and $2 / 84(2.4 \%)$ were homozygous wildtype, heterozygous and homozygous mutant for CCR5 respectively.

\section{Discussion}

The presence of antibodies with specificity for multiple HIV-1 proteins is one of the diagnostic hallmarks of infection with the HIV-1 virus. In virtually all patients infected with HIV-1 permanent anti-viral antibodies are detectable typically within 3 to 12 weeks following exposure to the virus, and continue to increase in titer during the early phase of infection. Following this early phase, anti-HIV-1 antibody titer generally remains constant until the end stages of AIDS when fluctuations in total anti-HIV immunoglobulin may occur. Several studies have attempted to evaluate the existence of individuals who have been at high-risk of exposure to presumably infectious HIV, but who have resisted HIV-1 infection. This work has focused on several populations of high-risk HIV-1 seronegative individuals including intravenous drug users [24-26], HIV-1 exposed health care workers [27-29], sexual partners of HIV-1 infected individuals [27,30-40], female sex workers who have engaged in repeated unprotected sex with HIV-1 infected partners [30-32,38-44], HIV-1 uninfected children born from HIV-1 infected mothers $[31,39,40,45,46]$ and hemophiliacs with a high probability of HIV-1 exposure from contaminated clotting factor concentrates $[7,47-50]$. 
Table 2: Transient HIV-I Seroactivity in HIV-Exposed Hemophiliacs

\begin{tabular}{|c|c|c|c|c|c|c|c|c|c|c|c|c|c|}
\hline \multicolumn{2}{|c|}{ Plasma Draw } & \multirow{2}{*}{$\begin{array}{l}\text { HIV-EIA } \\
\text { IS:C }\end{array}$} & \multicolumn{5}{|c|}{ HIV-Western blot lgG } & \multicolumn{5}{|c|}{ HIV-Western blot IgM } & \multirow{2}{*}{$\begin{array}{l}\text { **CCR5 } \\
\text { Deletion }\end{array}$} \\
\hline Patient\# & Date & & $\mathrm{pl}$ & p24 & p66 & gpl20 & gpl60 & $\mathrm{pl7}$ & p24 & p66 & gpl20 & gpl60 & \\
\hline \multirow[t]{5}{*}{ I } & 82 & 0 & - & - & - & - & - & - & - & - & - & - & $+/-$ \\
\hline & 83 & 1.065 & - & - & - & - & - & - & - & - & - & - & \\
\hline & 84 & 0 & - & - & - & - & - & - & - & - & - & - & \\
\hline & 86 & 0 & - & - & - & - & - & - & - & - & - & - & \\
\hline & 88 & 0 & - & - & - & - & - & - & - & - & - & - & \\
\hline \multirow[t]{6}{*}{2} & 81 & 0 & - & $+*$ & - & - & - & - & - & + & - & - & ND \\
\hline & 83 & 0 & - & + & - & - & - & - & - & + & - & - & \\
\hline & 84 & 0 & - & + & - & - & - & - & - & + & - & - & \\
\hline & 86 & 1.143 & - & + & - & - & - & - & - & + & - & - & \\
\hline & 87 & 0 & - & + & - & - & - & - & - & + & - & - & \\
\hline & 89 & 0 & - & + & - & - & - & - & - & + & - & - & \\
\hline \multirow[t]{6}{*}{3} & 81 & 0 & - & + & - & - & - & - & + & - & - & - & $+/+$ \\
\hline & 82 & 0 & - & $+*$ & - & - & - & - & + & - & - & - & \\
\hline & 84 & 0 & - & + & - & - & - & - & + & - & - & - & \\
\hline & 86 & 0 & - & + & - & - & - & - & + & - & - & - & \\
\hline & 89 & 0 & - & \pm & - & - & - & - & + & - & - & - & \\
\hline & 91 & 0 & - & \pm & - & - & - & - & + & - & - & - & \\
\hline \multirow[t]{5}{*}{4} & 83 & 0 & - & + & + & + & $+*$ & - & + & + & + & + & $+/+$ \\
\hline & 85 & 0 & - & + & - & - & - & - & - & - & - & - & \\
\hline & 86 & 0 & - & + & - & - & - & - & - & - & - & - & \\
\hline & 89 & 0 & - & + & - & - & - & - & - & - & - & - & \\
\hline & 92 & 0 & - & + & - & - & - & - & - & - & - & - & \\
\hline \multirow[t]{8}{*}{5} & 80 & 0 & - & - & - & - & - & - & - & - & - & - & $+/+$ \\
\hline & 81 & 2.437 & - & + & + & - & - & - & - & - & - & - & \\
\hline & 85 & 0 & - & + & + & - & - & - & - & - & - & - & \\
\hline & 86 & 0 & - & + & + & - & - & - & - & - & - & - & \\
\hline & 87 & 0 & & + & + & - & + & - & - & - & - & - & \\
\hline & 88 & 0 & - & - & - & - & - & - & - & - & - & - & \\
\hline & 90 & 0 & - & - & - & - & - & - & - & - & - & - & \\
\hline & 92 & 0 & - & - & - & - & - & - & - & - & - & - & \\
\hline \multirow[t]{6}{*}{6} & 81 & 0 & - & - & - & - & - & - & - & - & - & - & $+/+$ \\
\hline & 82 & 0 & - & - & - & - & - & - & - & - & - & - & \\
\hline & 85 & 1.519 & - & - & - & - & - & - & - & - & - & - & \\
\hline & 86 & 1.104 & - & - & - & - & - & - & - & - & - & - & \\
\hline & 87 & 1.117 & - & - & - & - & - & - & - & - & - & - & \\
\hline & 88 & 0 & - & - & - & - & - & - & - & - & - & - & \\
\hline \multirow[t]{3}{*}{7} & 82 & 1.143 & - & - & - & - & - & - & - & - & - & - & $+/+$ \\
\hline & 83 & 0 & - & - & - & - & - & - & - & - & - & - & \\
\hline & 86 & 0 & - & - & - & - & - & - & - & - & - & - & \\
\hline \multirow[t]{5}{*}{8} & 82 & 0 & - & + & - & - & - & $+*$ & + & - & - & - & $+/+$ \\
\hline & 84 & 0 & - & + & - & - & - & + & + & - & - & - & \\
\hline & 85 & 0 & - & + & - & - & - & + & + & - & - & - & \\
\hline & 86 & 0 & - & + & - & - & - & \pm & \pm & - & - & - & \\
\hline & 92 & 0 & - & + & - & - & - & \pm & \pm & - & - & - & \\
\hline \multirow[t]{6}{*}{9} & 80 & 0 & - & + & - & - & - & \pm & + & - & - & - & $+/+$ \\
\hline & 81 & 0 & - & + & - & - & - & + & + & - & - & - & \\
\hline & 82 & 0 & - & $+*$ & - & - & - & $+*$ & + & - & - & - & \\
\hline & 85 & 0 & - & + & - & - & - & + & + & - & - & - & \\
\hline & 87 & 0 & - & + & - & - & - & + & + & - & - & - & \\
\hline & 92 & 0 & - & + & - & - & - & + & + & - & - & - & \\
\hline
\end{tabular}


Table 2: Transient HIV-I Seroactivity in HIV-Exposed Hemophiliacs (Continued)

\begin{tabular}{|c|c|c|c|c|c|c|c|c|c|c|c|c|c|}
\hline \multirow[t]{7}{*}{10} & 81 & 0 & - & + & - & - & - & + & + & - & - & - & \multirow[t]{7}{*}{$+/+$} \\
\hline & 84 & 0 & - & + & - & - & - & + & + & - & - & - & \\
\hline & 85 & 0 & - & + & - & - & - & + & + & - & - & - & \\
\hline & 86 & 0 & - & + & - & - & - & + & + & - & - & - & \\
\hline & 89 & 0 & - & + & - & - & - & + & + & - & - & - & \\
\hline & 90 & 0 & - & + & - & - & - & + & + & - & - & - & \\
\hline & 92 & 0 & - & + & - & - & - & + & + & - & - & - & \\
\hline \multirow[t]{4}{*}{11} & 85 & 0 & - & - & - & - & - & - & + & - & - & - & \multirow[t]{4}{*}{-/- } \\
\hline & 86 & 0 & - & - & - & - & - & - & + & - & - & - & \\
\hline & 87 & 0 & - & - & - & - & - & - & + & - & - & - & \\
\hline & 89 & 0 & - & - & - & - & - & - & + & - & - & - & \\
\hline \multirow[t]{5}{*}{12} & 83 & 0 & - & - & \pm & - & - & - & - & - & - & - & \multirow[t]{5}{*}{$+/+$} \\
\hline & 84 & 0 & - & - & \pm & - & - & - & - & - & - & - & \\
\hline & 85 & 0 & - & - & \pm & - & - & - & - & - & - & - & \\
\hline & 87 & 0 & - & - & \pm & - & - & - & & - & - & - & \\
\hline & 91 & 0 & - & - & \pm & - & - & - & - & - & - & - & \\
\hline \multirow[t]{7}{*}{13} & 81 & 0 & - & + & - & - & - & - & \pm & - & - & - & \multirow[t]{7}{*}{$+/+$} \\
\hline & 82 & 0 & - & + & - & - & - & - & \pm & - & - & - & \\
\hline & 83 & 0 & - & + & - & - & - & - & \pm & - & - & - & \\
\hline & 84 & 0 & - & + & - & - & - & - & \pm & - & - & - & \\
\hline & 85 & 0 & - & + & - & - & - & - & \pm & - & - & - & \\
\hline & 87 & 0 & - & + & - & - & - & - & \pm & - & - & - & \\
\hline & 91 & 0 & - & + & - & - & - & - & \pm & - & - & - & \\
\hline \multirow[t]{6}{*}{14} & 80 & 0 & - & - & - & - & - & - & - & - & - & - & \multirow[t]{6}{*}{$+/-$} \\
\hline & 82 & 0 & - & - & - & - & - & - & - & - & - & - & \\
\hline & 84 & 0 & - & - & - & - & - & - & - & - & - & - & \\
\hline & 85 & 0 & - & - & - & - & - & - & - & - & - & - & \\
\hline & 86 & 0 & - & - & - & - & - & - & - & - & - & - & \\
\hline & 92 & 0 & - & - & - & - & - & - & - & - & - & - & \\
\hline \multirow[t]{5}{*}{15} & 83 & 0 & - & - & - & - & - & - & - & - & - & - & \multirow[t]{5}{*}{$+/+$} \\
\hline & 84 & 0 & - & - & - & - & - & - & - & - & - & - & \\
\hline & 85 & 0 & - & - & - & - & - & - & - & - & - & - & \\
\hline & 86 & 0 & - & - & - & - & - & - & - & - & - & - & \\
\hline & 91 & 0 & - & - & - & - & - & - & - & - & - & - & \\
\hline
\end{tabular}

IS:C Denotes the ratio of sample absorbance value to cut-off value.

*Sample displaying the most reactivity in archived plasma set with fluctuating anti-HIV-I antibody reactivity on WB analysis.

**CCR5 Deletion Analysis

ND $=$ not done

$+/+=$ wildtype,

$+/-=$ mutant heterozygous

$-/-=$ mutant homozygous

In this study we retrospectively identified transient antiHIV-1 antibody reactivity in archived plasma sets from currently HIV seronegative hemophiliacs who had a high probability of intravenous exposure to HIV contaminated CFCs. To accomplish this we used diagnostic methods for the detection of HIV reactive antibodies that are substantially more sensitive than earlier versions that were first introduction in the mid-80s when many of our plasma samples were originally tested and found to be negative. Confirmation of the current negative HIV status of the hemophiliacs whose archived samples were analyzed in this study was accomplished using HIV-I PCR analysis on recently obtained PBMC from these individuals.

Using HIV-EIA analysis we found that 5/15 (33\%) archived plasma sets contained samples transiently reactive at one or more time point in 1987 or before. HIV-EIA reactivity above baseline is seen in less than $0.2 \%$ of healthy blood donors with no known exposure to HIV (HIV-1/HIV-2 EIA packet insert, Abbott Laboratories). 
One interpretation of these results is that there was a temporary appearance of low level antibodies reactive with HIV antigens in some hemophiliacs during, or shortly after, the most likely time of exposure to infectious or non-infectious HIV-1 in contaminated CFCs (19801985). The level of reactivity that we detected on the HIVEIA was clearly above the baseline cut-off values determined by the respective controls for the assay, although lower than that typically seen in HIV-1 seropositive individuals.

None of the samples that were reactive on the HIV EIA showed reactivity against HIV-2 proteins by WB analysis suggesting that the HIV-2 antigens present on the EIA assay (Abbott Laboratories) were not likely responsible for the observed reactivity. The lack of anti-HIV-1 reactivity in samples older than those displaying reactivity suggested that these observations were not an artefact of the prolonged frozen storage of the plasma (Table 2, patient $1,2$ and $4-7)$.

Of the archived plasma sets that we tested, 10/15 (75\%) had detectable IgG and/or IgM antibodies reactive with one or more HIV antigen on HIV-Wb analysis, which was most commonly directed against the p24 group antigen (figure 1 and table 2). Although most of the $\mathrm{Wb}$ reactivity that we observed would be classified as HIV-1 indeterminate, one archived plasma sample set had fluctuating weak IgG reactivity against multiple HIV proteins which included p24, p66 and gp160. This individual was also reactive by HIV-EIA analysis but only in one year corresponding to $\mathrm{Wb}$ activity (table 2 , patient 5 ). A second hemophiliac, not reactive by HIV-EIA analysis, also had plasma antibodies reactive to HIV p24, p66, gp120 and gp160 antigens (Fig. 1, panel 4 and Table 2 patient 4). The p24 reactivity observed in this archived plasma set was consistently present in all of samples, however, the p66, gp120 and gp160 reactivity was observed only in the 1983 sample. Fluctuating anti-HIV reactive antibody titer was noted in samples from 5/10 (50\%) of the archived plasma sets (Fig. 1 strip set $2-4$ and Table 2, asterisks by patients 2-4, 8 and 9).

Indeterminate HIV-1 $\mathrm{WB}$ reactivity has been typically detected in only $5-7 \%$ of healthy EIA negative controls [51]. Although indeterminate results occurring in up to $32 \%$ of low-risk healthy populations have been reported with approximately half of these being attributable to p24 reactivity [52]. However, in our study, we observed that $10 / 15(67 \%)$ had indeterminate reactivity in the archived plasma sets that we tested from hemophiliacs exposed to HIV-1 contaminated CFCs. Not surprisingly, reactivity to the $\mathrm{p} 24$ group antigen was the most frequent pattern that we observed. Most individuals when exposed to infectious HIV-1 will develop anti-gp120/160 envelope antibodies in addition to the p24 core antigen. In contrast, exposure to lysed HIV virus results almost exclusively in an anti-p24 response (Steve Alexander, personnel observations). Based on the pattern of HIV-Wb reactivity observed in the archived plasma sets tested in this study, our population of hemophiliacs were likely exposed predominantly to inactivated HIV-1. It is also possible that patterns of $\mathrm{Wb}$ reactivity more consistent with exposure to infectious HIV-1 may have existed in the hemophiliacs that we studied but was at a time not available in our archived collection of samples.

Among the five archived plasma sets that contained samples displaying HIV-EIA reactivity, only two (40\%) also displayed HIV-Wb reactivity, which was not necessarily in corresponding years (Table 2., patients 2 and 4). Discrepancies between these two assays have previously been noted $[53,54]$. The HIV-Wb assay is an extremely sensitive method for the detection of antibodies which recognize predominantly, if not exclusively linearized epitopes. We have typically been able to detect anti-HIV serum antibodies from infected individuals when diluted more than a million fold. It is possible that the low level of reactivity noted in our archived plasma sets on HIV-Wb analysis may frequently have been beneath the limit of delectability by HIV-EIA. Discrepancies in reactivity between these two immunodiagnostic methods may also have resulted from the potential availability of conformational viral epitopes present on the HIV-EIA but not the HIV-Wb.

To determine whether archived plasma reactivity to HIV proteins could have been the result of passive acquired anti-HIV antibody contained in clotting factor concentrate, we assayed several concentrates made between 1981 and 1984 for the presence of anti-HIV-1 activity. One factor VIII concentrate from each of the 4 different U.S. manufacturers and one PCC made by the manufacturer that supplied over $90 \%$ of the PCCs used by our patient population were analyzed. Treatment with reconstituted clotting factor concentrate resulted in an approximate 1:100 dilution upon infusion into the blood stream $(50 \mathrm{ml}$ of reconstituted concentrate into 5 liters of whole blood). Accordingly, clotting factor concentrates were first diluted 1:100 prior to being run at the standard dilution for analysis (1:100 for HIV-Wb and 1:1.25 for the HIV-EIA). Under these parameters no anti-HIV reactivity was detectable in any of the clotting factor concentrates that were tested (data not shown). Additional studies in which clotting factor concentrates were spiked with limiting dilutions of HIV-1 specific antibodies were reactive indicating that the failure to detect anti-HIV antibodies was not due to interference by other clotting factor concentrate components (data not shown). Using more concentrated reconstituted clotting factor concentrates (a total dilution of $1: 50$ ) we could detect some HIV-Wb reactivity in all 
four of the factor VIII concentrates tested. This reactivity was with the p17, p24 and gp160 viral antigens, which confirms that CFCs were contaminated with blood products from HIV-seropositive donors (data not shown). Reactivity to the p17 and p160 viral proteins was rarely observed in the indeterminate samples from our archived plasma sets. This pattern of HIV-Wb reactivity would have been better represented in our archived plasma sets if the observed reactivity resulted from passively acquired antiHIV antibodies present in contaminated clotting factor concentrates and introduced to the patient at the time of CFC transfusion. HIV-1-negative individuals (2.4\%) had a slightly higher incidence of homozygosity for the deletion mutation of CCR5 compared with HIV-1-positive subjects $(0 \%)$. These values reflect essentially those observed in the normal population as well as those in large cohort hemophiliac populations published earlier [11-14,16]. In this study there was no apparent protective advantage of CCR- $5 \Delta 32$ heterozygosity in terms of HIV infection as has been reported previously [15-18].

\section{Conclusion}

Our results suggest that some severe hemophiliacs who were repeatedly exposed to CFCs contaminated with infectious and/or non-infectious HIV-1, immunologically processed some of the viral antigens but were not infected. It is expected that some of the HIV proteins in CFCs that the hemophiliacs in our study were exposed to would have been associated with non-infectious particles. However, we feel it likely that some of these individuals were transiently infected with HIV and then cleared the infection. The anti-HIV humoral reactivity that we detected would appear to be insufficient to abort a viral infection but the lack of any archived PBMC make it impossible to assess the degree to which any of our hemophiliacs may have mounted an anti-HIV cellular immune response at the time of exposure. It is also possible that some of the hemophiliacs in our study may have been exposed to an immunizing, but not infectious doses of HIV.

\section{Methods \\ Patients}

Archived plasma samples from 15 HIV seronegative individuals with either hemophilia A or B were selected for this study. All had been regularly followed by the Louisiana Comprehensive Hemophilia Care Center at Tulane University School of Medicine. Patient characteristics and clotting factor concentrate exposure history are given in table 1. Patients were chosen for study based upon use of clotting factor concentrates in excess of 5000 units per year from 1979 to 1985 and on availability of archived plasma samples for retrospective testing. At initial testing with first generation HIV enzyme linked immunosorbent assays (ELISA) in 1985 all of the individuals included in the present study were categorized as HIV seronegative.
All studies described below were performed on samples of citrated plasma that had been stored at $-70^{\circ} \mathrm{C}$.

\section{Detection of antibodies to HIV}

HIV-IAB HIV-IIHIV-2 (rDNA) EIA

Archived plasma samples were reassessed for the presence of plasma antibodies reactive with HIV-1 and/or HIV-2 antigens using the HIV-1AB HIV-1IHIV-2 (rDNA) EIA kit (HIV-BIA, Abbott Laboratories) and HIV-1 and HIV-2 Wb assays (Cambridge Biotech, Rockville, Maryland) according to the manufactures protocol. In brief, the HIV-EIA is a current generation ELISA (1992) that utilizes a polystyrene bead coated with recombinant HIV-1 Env and Gag peptides and HIV-2 Env peptides. Test or control plasma was incubated at a dilution of 1:1.25 with viral antigen coated beads. Following washing, HIV reactive antibodies were detected by incubation of the bead-antibody complex with horseradish-peroxidase labeled HIV-1 and HIV2 peptides that bind to all available open F'Ab sites. The enzyme-peptide-antibody complex was detected using a colorometric developing substrate solution comprised of 0 -phenylene diamine $2 \mathrm{HCl}$ and analyzed spectrophotometrically at a wavelength of $492 \mathrm{~nm}$. The frequency of reactivity on the HIV-EIA when tested on random blood donors is $0.16 \%$. (HIV-1AB HIV-1/HIV-2 (rDNA) EIA, manual 83-8291IR4, 1992. Abbott Laboratories).

\section{HIV-I and HIV-2 Wb}

HIV-1 and HIV-2 Wb analysis was performed using nitrocellulose strips containing electrophoretically separated and transferred proteins from inactivated HIV-1 or HIV-2 lysates. HIV-1 and HIV-2 Wb strips were subsequently incubated with test or control plasma at a dilution of $1: 100$. HIV reactive antibodies were visualized using biotinylated goat-anti human IgG and IgM, avidin-conjugated horseradish peroxidase and the colorimetric substrates 4chloro-l-naphthol. Results on the HIV-1 Wb were classified as negative if no bands are present, and positive if any two or more of the following bands were present; p24, gp4l, gp120 and gp160 and had a reactivity score equal to or greater than the weak positive control. Indeterminate classification was given when banding was present, but did not meet the criteria for a positive interpretation [55]. The frequency of seropositivity on the HIV-l Wb when tested on random blood donors is $0.15 \%$ (HIV-1 Cambridge Biotech HIV-1 Western blot kit package insert).

\section{Passive HIV reactive antibodies in clotting factor concentrates}

We assayed four factor VIII and one prothrombin complex concentrate (PCC) each manufactured between 1981 and 1984 for the presence of HIV reactive antibodies. All concentrates had been stored at $4{ }^{\circ} \mathrm{C}$ in their original sealed vials in a lyophilized state. Each was reconstituted for the present study according to the manufacturer's instructions 
using sterile water. Despite their age, all were readily reconstituted and had a normal appearance. Reconstituted concentrates were immediately aliquoted into $1 \mathrm{ml}$ cryovials and placed at $-70^{\circ} \mathrm{C}$ until their use [56]. To assess HIV reactivity, reconstituted factor concentrates were diluted $1: 1.33,1: 10,1: 50$, and $1: 250$ for HIV-1/HIV2 RIA analysis and 1:50, 1:100, 1:200, 1:400, 1:1,000, 1:5,000, and 1:10,000 for HIV-1 Wb analysis. To determine the degree to which other components in clotting factor concentrates may interfere with the EIA or the $\mathrm{Wb}$, a factor concentrate positive control was made by spiking aliquots of reconstituted clotting factor concentrates manufactured post 1990 with HIV-1 positive control sera and assayed for reduced reactivity.

\section{Determination of CCR-5 Genotype by PCR-RFLP}

Whole blood was lysed in RBC lysis solution (DNA isolation kit, Gentra Systems) for 1 minute at room temperature. Lysates were then centrifuged for 20 seconds at $13,000-16,000^{*} \mathrm{~g}$ and the supernant was removed. Cell pellets were vortexed in residual liquid and $300 \mu \mathrm{l}$ of cell lysis solution was added. CCR-5 genotyping was determined using PCR-RFLP as has been previously described.

\section{Confirmation of HIV infection status}

Due to the current HIV seronegative status of the hemophiliac population that we retrospectively analyzed in this study, it was considered unlikely that any were currently sub-clinically infected with HIV. However, to confirm this, recent peripheral blood mononuclear cell samples were assessed for the presence of HIV proviral DNA using HIV-1 PCR analysis.

\section{Competing interests}

The author(s) declare that they have no competing interests

\section{Authors' contributions}

SAT designed and performed the EIA and $\mathrm{Wb}$ experiments, analyzed the data and wrote the manuscript. Chemokine receptor PCR-RFLP was performed and analyzed by CAM and HEM. SSA provided intellectual assistance with $\mathrm{Wb}$ interpretation. RFG and CAL oversaw the design, development, implementation and analysis of the data for the project and edited the manuscript.

\section{Acknowledgements}

The authors wish to acknowledge the efforts of Ann Meyer M.T., A.S.C.P. in collecting and organizing archived plasma samples and to thank Ming Lu for technical assistance with PCR-RFLP assays. This work was supported in part by a Judith Graham Pool Postdoctoral Fellowship to SAT from The National Hemophilia Foundation. RFG was supported by NIH grants M25904, M34754 and DE 10862. CAL was supported by NIH grant HM6670.

\section{References}

I. Rein B, Wuiff K, Andes A: Hemophilia and HIV infection in Louisiana. Louisiana Morbidity Report 1988.

2. National Hemophilia Foundation: HIV seroprevalence in the Hemophilia Community. Hemophilia Information Exchange. Medical Bulletin . 1991 July 19

3. Kroner BL, Goedert JJ, Blattner WA, Wilson SE, Carrington MN, Mann DL: Concordance of human leukocyte antigen haplotype-sharing, CD4 decline and AIDS in hemophilic siblings. Multicenter Hemophilia Cohort and Hemophilia Growth and Development Studies. Aids 1995, 9(3):275-280.

4. Kroner BL, Rosenberg PS, Aledort LM, Alvord WG, Goedert J]: HIV$I$ infection incidence among persons with hemophilia in the United States and western Europe, 1978-1990. Multicenter Hemophilia Cohort Study. J Acquir Immune Defic Syndr 1994, 7(3):279-286.

5. Goedert JJ, Cohen AR, Kessler CM, Eichinger S, Seremetis SV, Rabkin CS, Yellin FJ, Rosenberg PS, Aledort LM: Risks of immunodeficiency, AIDS, and death related to purity of factor VIII concentrate. Multicenter Hemophilia Cohort Study. Lancet 1994, 344(8925):79|-792.

6. Goedert JJ, Garvey L, Hilgartner MW, Blatt PM, Aledort LM, Cohen AR, Kessler CM, White GC, Mandalaki T, Cook RA, et al.: Risk of HIV infection and AIDS in women and girls with coagulation disorders. Aids 1994, 8(4):564-565.

7. Ludlam CA, Tucker J, Steel CM, Tedder RS, Cheingsong-Popov R, Weiss RA, McClelland DB, Philp I, Prescott RJ: Human T-lymphotropic virus type III (HTLV-III) infection in seronegative haemophiliacs after transfusion of factor VIII. Lancet 1985, 2(8449):233-236.

8. Fabio G, Marchini M, Scorza Smeraldi R, Zarantonello M, Tarantini G, Gringeri A, Antonioli R: Possible association of HLA-DR2 phenotype and detectable human immunodeficiency virus (HIV) p24 antigen in HIV-positive patients. J Infect Dis 1993, I67(2):499-500.

9. Papasteriades C, Varla M, Economidou J, Marcacis K, Mitsouli C, Louisou K, Mandalaki T, Roumeliotou A, Papaevangelou G: High frequency of HLA-DR5 in Greek patients with haemophilia A and haemophilia B. Tissue Antigens 1986, 28(2):84-87.

10. Steel CM, Ludlam CA, Beatson D, Peutherer JF, Cuthbert RJ, Simmonds P, Morrison H, Jones M: HLA haplotype AI B8 DR3 as a risk factor for HIV-related disease. Lancet 1988, I (8596): | | 85-| | |88.

II. Dean M, Carrington M, Winkler C, Huttley GA, Smith MW, Allikmets R, Goedert JJ, Buchbinder SP, Vittinghoff E, Gomperts E, et al:: Genetic restriction of HIV-I infection and progression to AIDS by a deletion allele of the CKR5 structural gene. Hemophilia Growth and Development Study, Multicenter AIDS Cohort Study, Multicenter Hemophilia Cohort Study, San Francisco City Cohort, ALIVE Study. Science 1996, 273(5283): 1856-1862.

12. Liu R, Paxton WA, Choe S, Ceradini D, Martin SR, Horuk R, MacDonald ME, Stuhlmann H, Koup RA, Landau NR: Homozygous defect in HIV-I coreceptor accounts for resistance of some multiply-exposed individuals to HIV-I infection. Cell 1996, 86(3):367-377.

13. Samson M, Libert F, Doranz BJ, Rucker J, Liesnard C, Farber CM, Saragosti S, Lapoumeroulie C, Cognaux J, Forceille C, et al.: Resistance to HIV-I infection in caucasian individuals bearing mutant alleles of the CCR-5 chemokine receptor gene. Nature 1996, 382(6593):722-725.

14. Smith MW, Dean M, Carrington M, Winkler C, Huttley GA, Lomb DA, Goedert JJ, O'Brien TR, Jacobson LP, Kaslow R, et al.: Contrasting genetic influence of CCR2 and CCR5 variants on HIV-I infection and disease progression. Hemophilia Growth and Development Study (HGDS), Multicenter AIDS Cohort Study (MACS), Multicenter Hemophilia Cohort Study (MHCS), San Francisco City Cohort (SFCC), ALIVE Study. Science 1997, 277(5328):959-965.

15. Kantor R, Barzilai A, Varon D, Martinowitz U, Gershoni JM: Prevalence of a CCR5 gene 32-bp deletion in an Israeli cohort of HIV-I-infected and uninfected hemophilia patients. J Hum Virol 1998, I(4):299-30I.

16. Kupfer B, Kaiser R, Brackmann HH, Effenberger W, Rockstroh JK, Matz B, Schneweis KE: Protection against parenteral HIV-I 
infection by homozygous deletion in the $\mathrm{C}$-C chemokine receptor 5 gene. Aids 1999, 13(9): 1025-1028.

17. Pasi KJ, Sabin CA, Jenkins PV, Devereux HL, Ononye C, Lee CA: The effects of the 32-bp CCR-5 deletion on HIV transmission and HIV disease progression in individuals with haemophilia. $\mathrm{Br} J$ Haematol 2000, I I I(I): |36-|42.

18. Zamarchi R, Indraccolo S, Minuzzo S, Coppola V, Gringeri A, Santagostino E, Vicenzi E, De Silvestro G, Biagiotti R, Baldassarre C, et al. Frequency of a mutated CCR-5 allele (delta32) among Italian healthy donors and individuals at risk of parenteral HIV infection. AIDS Res Hum Retroviruses 1999, I 5(4):337-344.

19. Agius G, Biggar RJ, Alexander SS, Waters DJ, Drummond JE, Murphy EL, Weiss SH, Levine PH, Blattner WA: Human T lymphotropic virus type I antibody patterns: evidence of difference by age and risk group. J Infect Dis 1988, I 58(6): | 235-1244.

20. Burke DS, Redfield RR, Putman P, Alexander SS: Variations in Western blot banding patterns of human T-cell lymphotropic virus type III/lymphadenopathy-associated virus. J Clin Microbiol 1987, 25(I):81-84.

21. Dock NL, Lamberson HV Jr, O'Brien TA, Tribe DE, Alexander SS, Poiesz BJ: Evaluation of atypical human immunodeficiency virus immunoblot reactivity in blood donors. Transfusion 1988 28(5):4|2-4|8.

22. Farzadegan H, Polis MA, Wolinsky SM, Rinaldo CR Jr, Sninsky JJ, Kwok $S$, Griffith RL, Kaslow RA, Phair JP, Polk BF, et al.: Loss of human immunodeficiency virus type I (HIV-I) antibodies with evidence of viral infection in asymptomatic homosexual men. A report from the Multicenter AIDS Cohort Study. Ann Intern Med 1988, 108(6):785-790.

23. Farzadegan H, Taylor E, Hardy W, Odaka N, Polk BF: Performance of serological assays for early detection of human immunodeficiency virus type I seroconversion. J Clin Microbiol 1989, 27(8): 1882-1884.

24. Beretta A, Weiss SH, Rappocciolo G, Mayur R, De Santis C, Quirinale J, Cosma A, Robbioni P, Shearer GM, Berzofsky JA, et al: Human immunodeficiency virus type I (HIV-I)-seronegative injection drug users at risk for HIV exposure have antibodies to HLA class I antigens and T cells specific for HIV envelope. J Infect Dis 1996, 173(2):472-476.

25. Boiocchi M, Franceschi S, Serraino D, Guarneri S, Tavian M, Diodato $S$ : Persistent lack of human immunodeficiency virus infection in intravenous drug users at very high risk. J Acquir Immune Defic Syndr 1993, 6(6):633-635

26. Moore JD, Cone EJ, Alexander SS Jr: HTLV-III seropositivity in 197|-1972 parenteral drug abusers--a case of false positives for evidence of viral exposure? $N$ Engl J Med 1986, 3 I 4(2I): I387-I388

27. Clerici M, Giorgi JV, Chou CC, Gudeman VK, Zack JA, Gupta P, Ho HN, Nishanian PG, Berzofsky JA, Shearer GM: Cell-mediated immune response to human immunodeficiency virus (HIV) type I in seronegative homosexual men with recent sexual exposure to HIV-I. J Infect Dis 1992, 165(6):1012-1019.

28. Pinto LA, Landay AL, Berzofsky JA, Kessler HA, Shearer GM Immune response to human immunodeficiency virus (HIV) in healthcare workers occupationally exposed to HIVcontaminated blood. Am J Med 1997, I02(5B):2I-24.

29. Pinto LA, Sullivan J, Berzofsky JA, Clerici M, Kessler HA, Landay AL, Shearer GM: ENVspecific cytotoxic $T$ lymphocyte responses in HIV seronegative health care workers occupationally exposed to HIV-contaminated body fluids. J Clin Invest 1995, 96(2):867-876.

30. Detels R, Liu Z, Hennessey K, Kan J, Visscher BR, Taylor JM, Hoover DR, Rinaldo CR Jr, Phair JP, Saah AJ, et al.: Resistance to HIV-I infection. Multicenter AIDS Cohort Study. I Acquir Immune Defic Syndr 1994, 7( I 2): I263-1269.

31. Detels R, Mann D, Carrington M, Hennessey K, Wu Z, Hirji KF, Wiley $D$, Visscher BR, Giorgi JV: Resistance to HIV infection may be genetically mediated. Aids 1996, I0(I): 102-104.

32. Haynes BF, Pantaleo G, Fauci AS: Toward an understanding of the correlates of protective immunity to HIV infection. Science 1996, 27 I (5247):324-328.

33. Kelker HC, Seidlin M, Vogler M, Valentine FT: Lymphocytes from some long-term seronegative heterosexual partners of HIV infected individuals proliferate in response to HIV antigens. AIDS Res Hum Retroviruses 1992, 8(8): I 355-1359.
34. Langlade-Demoyen P, Ngo-Giang-Huong N, Ferchal F, Oksenhendler E: Human immunodeficiency virus (HIV) nef-specific cytotoxic T lymphocytes in noninfected heterosexual contact of HIV-infected patients. J Clin Invest 1994, 93(3): 1293-1297.

35. O'Brien TR, Blattner WA, Waters D, Eyster E, Hilgartner MW, Cohen AR, Luban N, Hatzakis A, Aledort LM, Rosenberg PS, et al:: Serum HIV-I RNA levels and time to development of AIDS in the Multicenter Hemophilia Cohort Study. Jama 1996, 276(2): $105-110$.

36. O'Brien TR, Padian NS, Hodge T, Goedert JJ, O'Brien SJ, Carrington M: CCR-5 genotype and sexual transmission of HIV-I. Aids 1998, I 2(4):444-445.

37. O'Brien TR, VanDevanter N, Paxton H, Polan C, Holmberg SD: CD4+ T-lymphocyte counts among seronegative heterosexual partners of persons infected with human immunodeficiency virus type I. J Acquir Immune Defic Syndr 1993, 6(I 2): 1 374-1375.

38. Rowland-Jones SL, Dong T, Fowke KR, Kimani J, Krausa P, Newell H, Blanchard T, Ariyoshi K, Oyugi J, Ngugi E, et al.: Cytotoxic T cell responses to multiple conserved HIV epitopes in HIV-resistant prostitutes in Nairobi. J Clin Invest 1998, 102(9): 1758- 1765.

39. Rowland-Jones SL, McMichael A: Immune responses in HIVexposed seronegatives: have they repelled the virus? Curr Opin Immunol 1995, 7(4):448-455.

40. Rowland-Jones SL, Nixon DF, Aldhous MC, Gotch F, Ariyoshi K, Hallam N, Kroll JS, Froebel K, McMichael A: HIV-specific cytotoxic T. cell activity in an HIV-exposed but uninfected infant. Lancet |993, 34 | (8849):860-86|.

4I. Fowke KR, Dong T, Rowland-Jones SL, Oyugi J, Rutherford WJ, Kimani J, Krausa P, Bwayo J, Simonsen JN, Shearer GM, et al.: HIV type I resistance in Kenyan sex workers is not associated with altered cellular susceptibility to HIV type I infection or enhanced betachemokine production. AIDS Res Hum Retroviruses 1998, I4(17): 1521-1530.

42. Fowke KR, Kaul R, Rosenthal KL, Oyugi J, Kimani J, Rutherford WJ, Nagelkerke NJ, Ball TB, Bwayo J], Simonsen JN, et al.: HIV-I-specific cellular immune responses among HIV-I-resistant sex workers. Immunol Cell Biol 2000, 78(6):586-595

43. Fowke KR, Nagelkerke NJ, Kimani J, Simonsen JN, Anzala AO, Bwayo J], MacDonald KS, Ngugi EN, Plummer FA: Resistance to HIV-I infection among persistently seronegative prostitutes in Nairobi, Kenya. Lancet 1996, 348(9038): |347-135|.

44. Rubsamen-Waigmann H, Maniar J, Gerte S, Brede HD, Dietrich U, Mahambre G, Pfutzner A: High proportion of HIV-2 and HIV-I/ 2 double-reactive sera in two Indian states, Maharashtra and Goa: first appearance of an HIV-2 epidemic along with an HIV-I epidemic outside of Africa. Zentralbl Bakteriol 1994, 280(3):398-402.

45. Bryson YJ, Pang S, Wei LS, Dickover R, Diagne A, Chen IS: Clearance of HIV infection in a perinatally infected infant. $N$ Engl J Med 1995, 332(13):833-838.

46. Bryson YJ, Pang S, Wi L: A child found to be HIV positive shortly after birth appears now to be clear of the infection. Nurs Times 1995, 9 I(I5): II.

47. Chelucci C, Hassan HJ, Gringeri A, Macioce G, Mariani G, Santagostino E, Testa U, Vulcano F, Mannucci PM, Peschle C: PCR analysis of HIV-I sequences and differential immunological features in seronegative and seropositive haemophiliacs. $\mathrm{Br}\rfloor$ Haematol 1992, 8I(4):558-567.

48. Lederman MM, Jackson JB, Kroner BL, White GC 3rd, Eyster ME, Aledort LM, Hilgartner MW, Kessler CM, Cohen AR, Kiger KP, et al: Human immunodeficiency virus (HIV) type I infection status and in vitro susceptibility to HIV infection among high-risk HIV-I-seronegative hemophiliacs. I Infect Dis 1995, I 72(I):228-23I.

49. Shoebridge GI, Barone L, Wing-Simpson A, Bennetts BH, Nightingale BN, Hensley W], Gatenby PA: Assessment of HIV status using the polymerase chain reaction in antibodypositive patients and high-risk antibody-negative haemophiliacs. Aids |99|, 5(2):22I-224

50. Shoebridge GI, Gatenby PA, Nightingale BN, Barone L, Wing-Simpson $\mathrm{A}$, Bennetts BH, Hensley W]: Polymerase chain reaction testing of HIV-I seronegative at-risk individuals. Lancet 1990 , 336(8708): $180-181$.

51. Talal N, Dauphinee MJ, Dang H, Alexander SS, Hart DJ, Garry RF: Detection of serum antibodies to retroviral proteins in 
patients with primary Sjogren's syndrome (autoimmune exocrinopathy). Arthritis Rheum 1990, 33(6):774-781.

52. Midthun K, Garrison L, Clements ML, Farzadegan H, Fernie B, Quinn $\mathrm{T}$ : Frequency of indeterminate western blot tests in healthy adults at low risk for human immunodeficiency virus infection. The NIAID AIDS Vaccine Clinical Trails Network. J Infect Dis 1990, 162(6): 1379-1382.

53. Downie JC, Howard R, Bowcock B, Cunningham AL: HIV-I antibody testing strategy: evaluation of ELISA screening and western blot profiles in a mixed low risk/high risk patient population. J Virol Methods 1989, 26(3):291-303.

54. Portincasa P, Conti G, Zannino T, Visalli S, Chezzi C: Radioimmune western blotting in comparison with conventional western blotting, second and third generation ELISA assays for the serodiagnosis of HIV-I infection. New Microbiol 1994, I7(3): $169-176$.

55. Interpretation and use of the Western blot assay for serodiagnosis of human immunodeficiency virus type $I$ infections. MMWR 1989, 38:I-7.

56. Leissinger CA, Stuckey W]: Unbound immunoglobulins are a major source of error in the quantitation of platelet surfacebound immunoglobulin levels. Transfusion 1992, 32(2): I57-I6I.

Publish with Bio Med Central and every scientist can read your work free of charge

"BioMed Central will be the most significant development for disseminating the results of biomedical research in our lifetime. "

Sir Paul Nurse, Cancer Research UK

Your research papers will be:

- available free of charge to the entire biomedical community

- peer reviewed and published immediately upon acceptance

- cited in PubMed and archived on PubMed Central

- yours - you keep the copyright 